\title{
Cytochrome P450 Hydroxylase TnmL Catalyzing Sequential Hydroxylation with an Additional Proof-reading Activity in Tiancimycin Biosynthesis
}

Thibault Annaval, ${ }^{1}$ Christiana N. Teijaro, ${ }^{1}$ Ajeeth Adhikari, ${ }^{1}$ Xiaohui Yan, ${ }^{1}$ Jian-Jun Chen, ${ }^{1}$ Ivana Crnovcic, ${ }^{1}$ Dong Yang, ${ }^{1,3}$ Ben Shen ${ }^{1,2,3, *}$

${ }^{1}$ Department of Chemistry, ${ }^{2}$ Department of Molecular Medicine, ${ }^{3}$ Natural Products Discovery Center at Scripps Research, The Scripps Research Institute, Jupiter, Florida 33458, United States

*To whom correspondence should be addressed: The Scripps Research Institute, 130 Scripps Way, \#3A1, Jupiter, FL 33458; Tel: (561) 228-2456, Email: shenb@scripps.edu

\section{Supplementary Information}

Table of Contents

Supplementary Material and Methods. S2-S5

\section{Supplementary Tables}

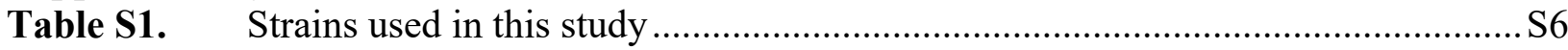

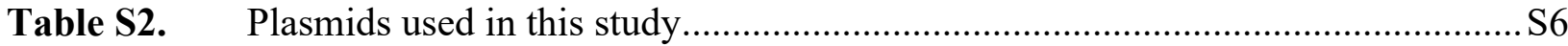

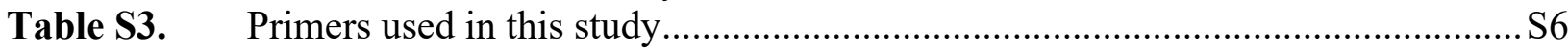

\section{Supplementary Figures}

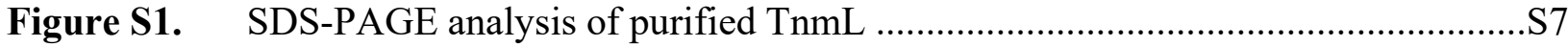

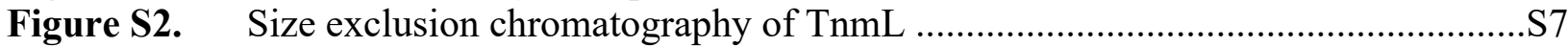

Figure S3. In vitro assays of TnmL using reductive activation of molecular oxygen ...........S8

Figure S4. Determination of the optimal $\mathrm{pH}$ for TnmL ................................................

Figure S5. Determination of the optimal $\mathrm{H}_{2} \mathrm{O}_{2}$ concentration for $\mathrm{TnmL}$.............................S9

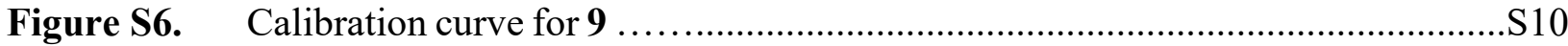

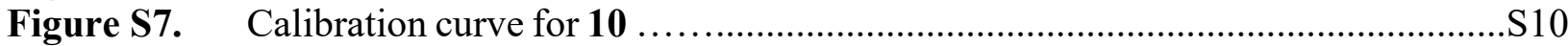

Figure S8. Steady-state kinetics for TnmL-catalyzed hydroxylation of 8 and $\mathbf{9}$................S1 1

Figure S9. TnmL-catalyzed reaction of alternative substrates 2, 3, 7, and the cycloaromatized product of 7

Figure S10. Binding assays of TnmL with 2, 3, 8, 9, 10, 11, 12, 7, and

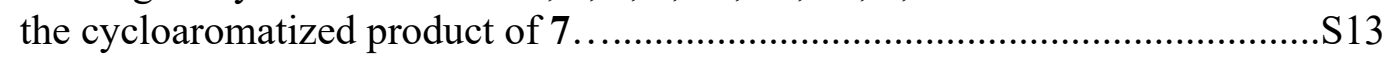

Figure S11. TnmL-catalyzed net demethylation in TNM A biosynthesis. ...........................S14

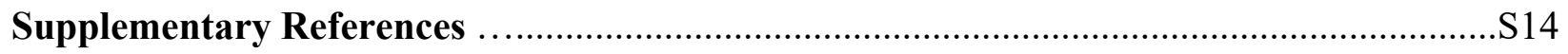




\section{Supplementary Materials and Methods}

General experimental procedures. The proteins were purified on an ÄKTA Pure (GE Healthcare Life Sciences). UV-vis spectra were measured with a NanoDrop 2000C spectrophotometer (Thermo Scientific). LC-MS was performed on an Agilent 1260 Infinity LC coupled to a 6230 TOF (HR-ESI). HPLC was performed on an Agilent 1260 Infinity II.

Bacterial strains, plasmids, and chemicals. Strains, plasmids, and PCR primers used in this study are listed in Tables S1-S3, respectively. PCR primers were obtained from Sigma-Aldrich. Q5 high-fidelity DNA polymerase, restriction endonucleases, and T4 DNA ligase were purchased from New England Biolabs (NEB) and used by following the protocols provided by the manufacturers. DNA amplification and mutagenesis were performed with a S1000 Thermal cycler (Bio-Rad). DNA gel extraction and plasmid preparation kits were purchased from Omega Bio-Tek. DNA sequencing was conducted by Eton Bio-science. Streptomyces sp. CB03234, the $\Delta t n m L$ mutant SB20020,,$^{1,2}$ and $\Delta t n m H$ mutants SB20002 $2^{1,2}$ and SB20024 $4^{3}$ were previously reported. Other common chemicals, biochemicals, and media components were purchased from standard commercial sources.

Culture conditions. E. coli strains containing plasmids or cosmids were cultured in lysogeny broth (LB) with the appropriate antibiotic. Streptomyces strains were grown on ISP4 medium at $28{ }^{\circ} \mathrm{C}$ for sporulation or cultured in liquid tryptic soy broth (TSB) at $28^{\circ} \mathrm{C}$ and $250 \mathrm{rpm}$, with appropriate antibiotic selection, if needed. Fermentation of the $S$. sp. CB03234 wild-type and S. sp. SB20002, SB20020, and SB20024 mutant strains were conducted as previously described. ${ }^{1-3}$ Briefly, fresh spores of Streptomyces strains were inoculated into TSB seed medium and culture for 2-3 days. TNM production medium was inoculated with $1 \%(\mathrm{v} / \mathrm{v})$ seed culture and $1.5 \%(\mathrm{w} / \mathrm{v})$ Dianion HP2MG resin (Sigma-Aldrich) and incubated at $28{ }^{\circ} \mathrm{C}$ and $250 \mathrm{rpm}$ for 5-7 days. After fermentation of the Streptomyces strains, the resin was harvested by centrifugation or decanting the supernatant, washed three times with $\mathrm{H}_{2} \mathrm{O}$, and extracted three times with ethyl acetate. The combine extracts were concentrated under vacuum and purified following previously reported protocols. ${ }^{1-3}$

Gene cloning. The tnmL gene from $S$. sp. CB03234 was amplified by PCR from the cosmid pBS20002 (Table S1), using the primers (Table S3) and Q5 High-Fidelity DNA Polymerase (NEB) and following the protocol provided by the manufacturer (Table S2). The amplified tnmL sequence was cloned into the NdeI and XhoI sites of pET28a (Novagen) to give pBS20036.

Gene expression and protein production and purification. pBS20036 was transformed into $E$. coli BL21 (DE3) (Table S1). The cells were grown in lysogeny broth supplemented at $37^{\circ} \mathrm{C}$ until an $\mathrm{OD}_{600}$ of 0.6 was reached. The cells were cooled to $4{ }^{\circ} \mathrm{C}$, the genes were induced by addition of $0.1 \mathrm{mM}$ of isopropyl $\beta$-D-1-thiogalactopyranoside. The cultures were supplemented with 0.1 $\mathrm{mM}$ of 5 -aminolevulinic acid and $0.1 \mathrm{mM}$ of $\mathrm{FeCl}_{3}$. The cells were grown at $18{ }^{\circ} \mathrm{C}$ for $16 \mathrm{~h}$. The cells were harvested at $4000 \times \mathrm{g}$ for $15 \mathrm{~min}$ at $4{ }^{\circ} \mathrm{C}$, and the pellet was resuspended in lysis buffer (100 mM Tris, $\mathrm{pH} 8.0$, containing $300 \mathrm{mM} \mathrm{NaCl}, 15 \mathrm{mM}$ imidazole, and $10 \%$ glycerol). After sonication, the cell debris was removed by centrifugation at $15000 \times \mathrm{g}$ for $15 \mathrm{~min}$ at $4{ }^{\circ} \mathrm{C}$. The lysate was loaded onto a HisTrap $5 \mathrm{~mL}$ column (GE) equilibrated with washing buffer (50 mM Tris, $\mathrm{pH} 8.0$, containing $100 \mathrm{mM} \mathrm{NaCl}$ and $15 \mathrm{mM}$ imidazole). The column was washed with 
washing buffer, and the $\mathrm{His}_{6}$-tagged protein was eluted using elution buffer (50 mM Tris, $\mathrm{pH} 8.0$, containing $100 \mathrm{mM} \mathrm{NaCl}$ and $300 \mathrm{mM}$ imidazole). Following elution, the protein was diluted three times using $50 \mathrm{mM}$ Tris, $\mathrm{pH} 8.0$ buffer. The protein was loaded onto a HiTrap Q HP 5mL (GF) equilibrated with washing buffer $(50 \mathrm{mM}$ Tris, $\mathrm{pH} 8.0)$. The column was washed with washing buffer, and the protein was eluted using a gradient of elution buffer $(50 \mathrm{mM}$ Tris, $\mathrm{pH} 8.0$, containing $1 \mathrm{M} \mathrm{NaCl}$ ). Finally, the protein was injected onto a Superdex S75 16/600 gel filtration column (GF) using $50 \mathrm{mM}$ Tris, $\mathrm{pH} 8.0$ buffer containing $100 \mathrm{mM} \mathrm{NaCl}$, and purified protein was stored at $-80{ }^{\circ} \mathrm{C}$.

Analytical size-exclusion chromatography. The molecular weight (MW) and monomeric state of TnmL in solution was determined by size-exclusion chromatography using a HiLoad 16/600 (16 $\times 600 \mathrm{~mm}$ ) Superdex 75 column (GE Healthcare) connected to a GE Healthcare ÄKTA pure HPLC

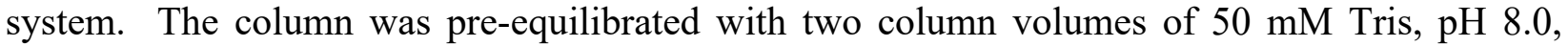
containing $100 \mathrm{mM} \mathrm{NaCl}$, and calibrated with carbonic anhydrase $(29 \mathrm{kDa})$, ovalbumin $(43 \mathrm{kDa})$, albumin $(66 \mathrm{kDa})$, conalbumin $(75 \mathrm{kDa})$, alcohol dehydrogenase $(150 \mathrm{kDa})$ and $\beta$-amylase $(200$ $\mathrm{kDa}$ ). The chromatography was carried out at $4{ }^{\circ} \mathrm{C}$ at a flow rate of $1 \mathrm{~mL} \mathrm{~min}{ }^{-1}$. Data analysis was performed using the Unicorn 7.0.2 software (GE Healthcare).

P450 spectral assay. TnmL was diluted in $100 \mathrm{mM} \mathrm{K}_{2} \mathrm{HPO}_{4}, \mathrm{pH} 7.5$, containing $1 \mathrm{mM}$ EDTA, $20 \%$ glycerol, $0.5 \%$ sodium cholate, and $0.4 \%$ Triton $\mathrm{N}-101$ to a final concentration of $50 \mu \mathrm{M}$. Then, $1 \mathrm{mg} \mathrm{mL}^{-1}$ of $\mathrm{Na}_{2} \mathrm{~S}_{2} \mathrm{O}_{2}$ was added to reduce the protein. Beforehand, half of the protein was bubbled with $\mathrm{CO}$ gas for $1 \mathrm{~min}$. Then a UV-vis spectrum of the ferrous-TnmL and the ferrousTnmL-CO was measured. The ferric-TnmL was used as a blank. ${ }^{4}$

TnmL activity assays using reductive activation of molecular oxygen or $\mathrm{H}_{2} \mathrm{O}_{2}$. Preliminary activity assays have been performed by mixing $1 \mathrm{mM}$ of $\mathbf{8}, 10 \mu \mathrm{M}$ of TnmL, and an external electron donor system. We used 1) $40 \mu \mathrm{M}$ of CamB (ferredoxin) and $40 \mu \mathrm{M}$ of CamA (ferredoxin reductase) from Pseudomonas putid ${ }^{5}$ and $5 \mathrm{mM}$ of NADH or 2) $1 \mathrm{mM}$ of ferredoxin and $1 \mathrm{mM}$ of ferredoxin reductase from Spinacia olerace ${ }^{6}$ and $5 \mathrm{mM}$ of NADPH. Reaction conditions resulted in the cycloaromatization of the enediyne core. ${ }^{7}$ To bypass the requirement of reductive activation of $\mathrm{O}_{2}$ by external redox partners, we use 3) $50 \mathrm{mM}$ of $\mathrm{H}_{2} \mathrm{O}_{2}$ directly to exploit the peroxide shunt pathway of the $\mathrm{P} 450$ catalytic cycle. Reactions were performed in $20 \mu \mathrm{L}$ and incubated for $1 \mathrm{~h}$ at $28^{\circ} \mathrm{C}$. Each reaction was quenched by the addition of $30 \mu \mathrm{L}$ of acetonitrile. After centrifugation, $10 \mu \mathrm{L}$ were injected and analyzed by LC-MS with an Eclipse Plus 120 Phenyl-Hexyl column (Agilent, $250 \mathrm{~mm} \times 4.6 \mathrm{~mm}$ ) with UV detection at $539 \mathrm{~nm}$ using the methods described below. Method I, the mobile phase was composed of $\mathrm{A}\left(\mathrm{H}_{2} \mathrm{O}\right.$ containing $0.1 \%$ formic acid $)$ and buffer $\mathrm{B}$ $\left(\mathrm{CH}_{3} \mathrm{CN}\right)$ using a linear solvent gradient from $5-100 \%$ for $18 \mathrm{~min}$ at a flow rate of $0.4 \mathrm{~mL} \mathrm{~min}^{-1}$. Method II, the mobile phase was composed of buffer $\mathrm{A}\left(\mathrm{H}_{2} \mathrm{O}\right.$ containing $0.1 \%$ formic acid $)$ and buffer $\mathrm{B}\left(\mathrm{CH}_{3} \mathrm{CN}\right)$ and the following method was used: equilibration to $30 \%$ buffer $\mathrm{B}$ for $5 \mathrm{~min}$, followed by a linear gradient of $30 \%$ buffer B to $70 \%$ buffer B for $10 \mathrm{~min}$, then a linear gradient of $70 \%$ buffer B to $100 \%$ buffer B for $3 \mathrm{~min}$, and $100 \%$ buffer B for $5 \mathrm{~min}$ at a flow rate of $0.4 \mathrm{~mL}$ $\mathrm{min}^{-1}$. Method III, the mobile phase was composed of $30 \%$ buffer $\mathrm{A}\left(\mathrm{H}_{2} \mathrm{O}\right.$ containing $0.1 \%$ formic acid) and $70 \%$ buffer $\mathrm{B}\left(\mathrm{CH}_{3} \mathrm{OH}\right)$ with isocratic elution at a flow rate of $1 \mathrm{~mL} \mathrm{~min}^{-1}$.

Optimization of TnmL-catalyzed hydroxylation in vitro. To determine the $\mathrm{pH}$ optimal for TnmL, reactions containing $1 \mathrm{mM}$ of $\mathbf{8}, 50 \mathrm{mM}$ of $\mathrm{H}_{2} \mathrm{O}_{2}$, and $10 \mu \mathrm{M}$ of TnmL in various buffers 
with pHs ranging from $5.5-9.0$ were performed in $20 \mu \mathrm{L}$ volumes and incubated for $1 \mathrm{~h}$ at $28^{\circ} \mathrm{C}$. Buffers tested were $50 \mathrm{mM}$ MES, $100 \mathrm{mM} \mathrm{NaCl}$ at pH 5.5 and $6.0 ; 50 \mathrm{mM}$ phosphate, $100 \mathrm{mM}$ $\mathrm{NaCl}$ at $\mathrm{pH} 6.0,6.5,7.0,7.5$ and 8.0 ; and $50 \mathrm{mM}$ Tris, $100 \mathrm{mM} \mathrm{NaCl}$ at $\mathrm{pH} 8.0,8.5$ and 9.0. Each reaction was quenched by the addition of $30 \mu \mathrm{L}$ of acetonitrile. After centrifugation, $10 \mu \mathrm{L}$ were injected and analyzed by HPLC equipped with an Eclipse Plus 120 Phenyl-Hexyl column (Agilent, $250 \mathrm{~mm} \times 4.6 \mathrm{~mm}$ ) with UV detection at $539 \mathrm{~nm}$. The mobile phase was composed of buffer A $\left(\mathrm{H}_{2} \mathrm{O}, 0.1 \%\right.$ formic acid) and buffer $\mathrm{B}\left(\mathrm{CH}_{3} \mathrm{CN}\right)$ and, method II developed for 8 was used. The areas of the peaks corresponding to the product were integrated and the concentrations were obtained using the calibration curve of the 9 (Figure S6).

To determine the optimal $\mathrm{H}_{2} \mathrm{O}_{2}$ concentration for TnmL, reactions containing $50 \mu \mathrm{M}$ of 8 or 9 and $2.2 \mu \mathrm{M}$ of TnmL in $50 \mathrm{mM}$ phosphate buffer, $\mathrm{pH} 7.0$ at various $\mathrm{H}_{2} \mathrm{O}_{2}$ concentration $(0.5,2,5,20$, 50 and $500 \mathrm{mM}$ ) were measured. Each reaction was quenched by the addition of $30 \mu \mathrm{L}$ of acetonitrile. After centrifugation, $10 \mu \mathrm{L}$ were injected and analyzed by HPLC equipped with an Eclipse Plus 120 Phenyl-Hexyl column with UV detection at $539 \mathrm{~nm}$. For the reaction with 8 as a substrate, the mobile phase was composed of buffer $\mathrm{A}\left(\mathrm{H}_{2} \mathrm{O}, 0.1 \%\right.$ formic acid) and buffer $\mathrm{B}$ $\left(\mathrm{CH}_{3} \mathrm{CN}\right)$, and method II developed for $\mathbf{8}$ was used. For those with $\mathbf{9}$ as a substrate, the mobile phase was composed of buffer $\mathrm{A}\left(\mathrm{H}_{2} \mathrm{O}, 0.1 \%\right.$ formic acid $)$ and buffer $\mathrm{B}\left(\mathrm{CH}_{3} \mathrm{OH}\right)$, and this method III developed for 9 was used consisting to an isocratic elution at $70 \%$ of buffer B at a flow rate of $1 \mathrm{~mL} \mathrm{m^{-1 }}$ during $30 \mathrm{~min}$. The area of the peaks corresponding to 8 or 9 were integrated and the concentrations of the products were obtained using the calibration curve of the $\mathbf{9}$ and $\mathbf{1 0}$ standards (Figure S6 and S7).

Initial rate measurements for the determination of kinetic parameters were carried out in $50 \mathrm{mM}$ phosphate buffer, $\mathrm{pH} 7.0$ and $5 \mathrm{mM}$ of $\mathrm{H}_{2} \mathrm{O}_{2}$ at various $8(0.5,1,5,10,30,50,100$ and $150 \mu \mathrm{M})$ and $9(0.5,0.75,1,5,10,50,100$ and $150 \mu \mathrm{M})$ concentrations during $1 \mathrm{~h}$ at $28^{\circ} \mathrm{C}$. The reactions were quenched and analyzed, depending on the substrate, as described above for the optimization of the $\mathrm{H}_{2} \mathrm{O}_{2}$ concentration (i.e., method II developed for $\mathbf{8}$ and method III developed for $\mathbf{9}$ were used, respectively). The data were analyzed using curve fitting to the Michaelis-Menten equation using nonlinear regression analysis on GraphPad Prism.

For evaluation of substrate promiscuity, compounds at $100 \mu \mathrm{M}$ were mixed with $5 \mathrm{mM} \mathrm{H}_{2} \mathrm{O}_{2}$ and $11 \mu \mathrm{M}$ of TnmL in $50 \mathrm{mM}$ phosphate buffer, $\mathrm{pH} 7$ for $1 \mathrm{~h}$ at $28^{\circ} \mathrm{C}$. Each reaction was quenched and analyzed by HPLC equipped with an Eclipse Plus 120 Phenyl-Hexyl column with UV detection at $539 \mathrm{~nm}$ as described above using the described HPLC conditions for method II.

Enzyme reaction of TnmL with substrate $\mathbf{1 1}$ resulted in the formation of $\mathbf{9}$ instead of $\mathbf{1 2}$ as evident by authentic standards of 9 and HR-MS. TNM F (9): HR-ESI-MS (positive ion) affording the [M $+\mathrm{H}]^{+}$ion at $m / z 560.1165$ (calcd $[\mathrm{M}+\mathrm{H}]^{+}$ion for molecular formula $\mathrm{C}_{29} \mathrm{H}_{22} \mathrm{NO}_{11}$ at $m / z$ 560.1193). 


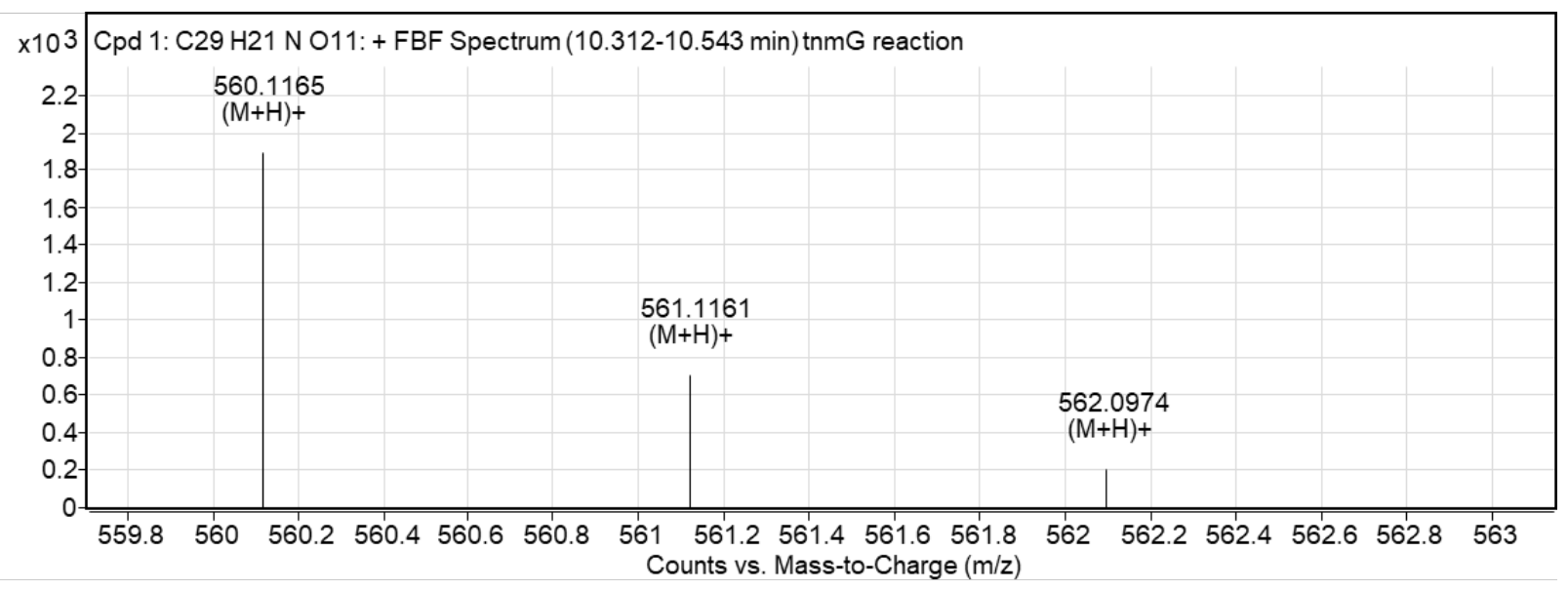

Binding assay. TnmL $(25 \mu \mathrm{M})$ was mixed with different concentrations of $\mathbf{2}, \mathbf{3}, \mathbf{7}, \mathbf{8}, \mathbf{9}, \mathbf{1 0}, \mathbf{1 1}$, 12, and the cycloaromatized product of $\mathbf{7}$. At each concentration, a UV-Vis spectrum was measured and the difference of absorbance between $390 \mathrm{~nm}$ and $420 \mathrm{~nm}$ were calculated. GraphPad Prism was used to calculate the apparent binding constants $\left(K_{\mathrm{D}}\right)$ by fitting spectral data into the following equation: $\left.\Delta \mathrm{A}_{390 \mathrm{~nm}-420 \mathrm{~nm}}=\left(\Delta \max _{390 \mathrm{~nm}-420 \mathrm{~nm}}[\mathrm{~S}]\right) /\left(K_{\mathrm{D}}+[\mathrm{S}]\right)\right)^{8,9}$ 
Table S1. Strains used in this study

\begin{tabular}{lll}
\hline Strain & Description & Source (Reference) \\
E. coli DH5 $\alpha$ & E. coli host for general cloning & Life Technologies \\
E. coli BL21(DE3) & E. coli host for protein overproduction & Life Technologies \\
Streptomyces sp. CB03234 & TNM producing organism & $(1)$ \\
$S$. sp. SB20020 & The $\Delta t n m L$ mutant strain of $S$. sp. CB03234 & $(2)$ \\
S. sp. SB20002 & The $\Delta t n m H$ mutant strain of $S$. sp. CB03234 & $(1,2)$ \\
$S$. sp. SB20024 & The $\Delta t n m L$ mutant strain of $S$. sp. & $(3)$ \\
& CB03234-S & \\
\hline
\end{tabular}

Table S2. Plasmids and cosmids used in this study

\begin{tabular}{|c|c|c|}
\hline Plasmid & Description & Source (Reference) \\
\hline pBS20002 & $\begin{array}{l}\text { cosmid containing the partial } t n m \text { gene } \\
\text { cluster }\end{array}$ & (1) \\
\hline pET28a & $\begin{array}{l}\text { General cloning vector for } E \text {. coli for } \\
\text { protein overproduction }\end{array}$ & Novagen \\
\hline pBS20036 & $\begin{array}{l}\text { pET28a harboring the full length tnmL; used } \\
\text { for TnmL overproduction and assays }\end{array}$ & This study \\
\hline
\end{tabular}

Table S3. Primers used in this study with restriction enzyme sites underlined.

\begin{tabular}{lll}
\hline Primer & Nucleotide Sequence (5'-3') & Function \\
TnmL-F & GTCAGGAGGTACGTCATATGGCCG & $\begin{array}{l}\text { tnmL amplification from } \\
\text { cosmid pBS20002 } \\
\text { tnmL amplification from } \\
\text { TnmL-R }\end{array}$ \\
& CTCGTCACGACTCGAGTCACGTCCG & \begin{tabular}{l} 
cosmid pBS20002 \\
\hline
\end{tabular}
\end{tabular}


Figure S1. SDS-PAGE analysis of purified TnmL. The molecular weight (MW) marker used is the Unstained Protein Ladder (NEB). The calculated expected MW of TnmL is $46.2 \mathrm{kDa}$.

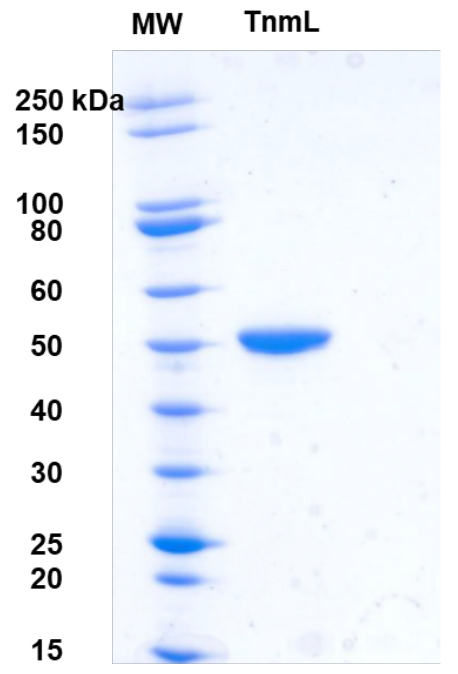

Figure S2. Size-exclusion chromatography of TnmL. TnmL (red circle) eluted at a retention time of $58.3 \mathrm{~mL}$, correlating to a molecular weight (MW) of $48 \mathrm{kDa}$. The calculated $\mathrm{MW}$ for the monomer of TnmL is $46.2 \mathrm{kDa}$.

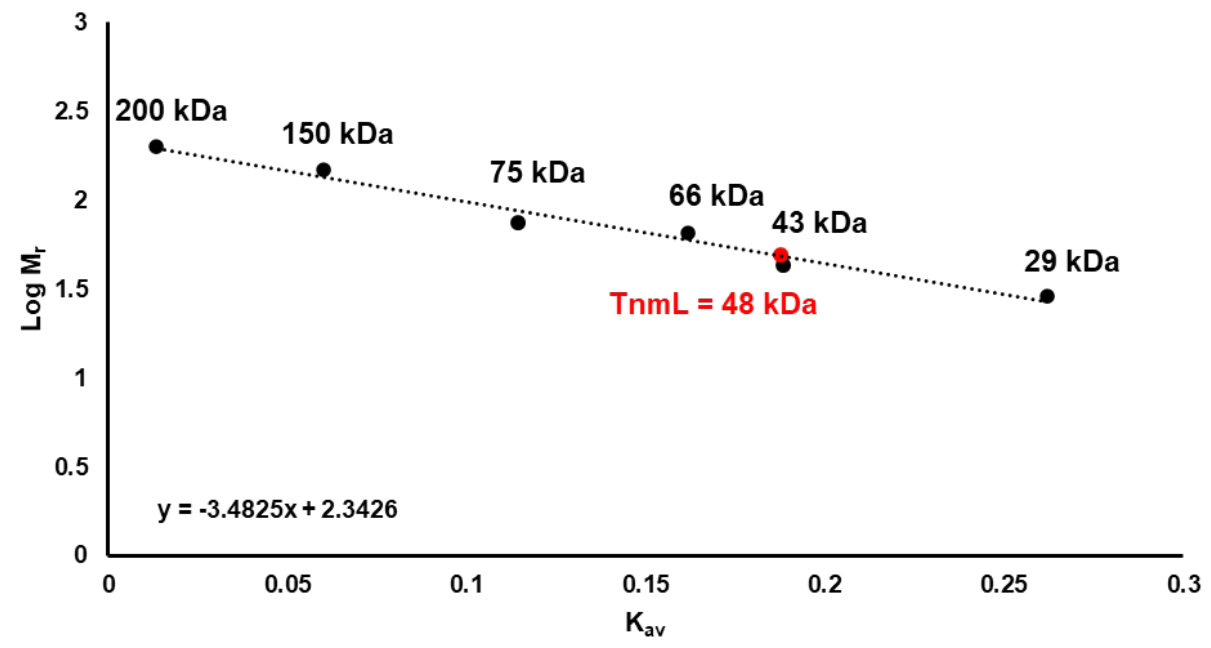


Figure S3. Determination of the source for cycloaromatization in the TnmL in vitro assay. (A) P450 redox partner ferredoxin/ferredoxin reductase catalyzed reductive cycloaromatization of anthraquinone-fused enediynes as exemplified by TNM E (8) to its cycloaromatized product 15.7 (B) HPLC analysis (by method I) of in vitro assays of TnmL using reductive activation of molecular oxygen:5,6,10,11 (i) 8 standard; (ii) 15 standard; (iii) $\mathbf{8}$ standard + NADH; (iv) 8 standard + NADPH; (v) 8 standard + CamB from Pseudomonas putida; (vi) 8 standard + CamA from Pseudomonas putida; (vii) 8 standard + ferredoxin from Spinacia oleracea; (viii) 8 standard + ferredoxin reductase from Spinacia oleracea; (ix) $\mathbf{8}$ standard + NADH + CamB from Pseudomonas putida; (x) 8 standard + NADH + CamA from Pseudomonas putida; (xi) 8 standard + NADPH + ferredoxin from Spinacia oleracea; (xii) 8 standard + NADPH + ferredoxin reductase from Spinacia oleracea.
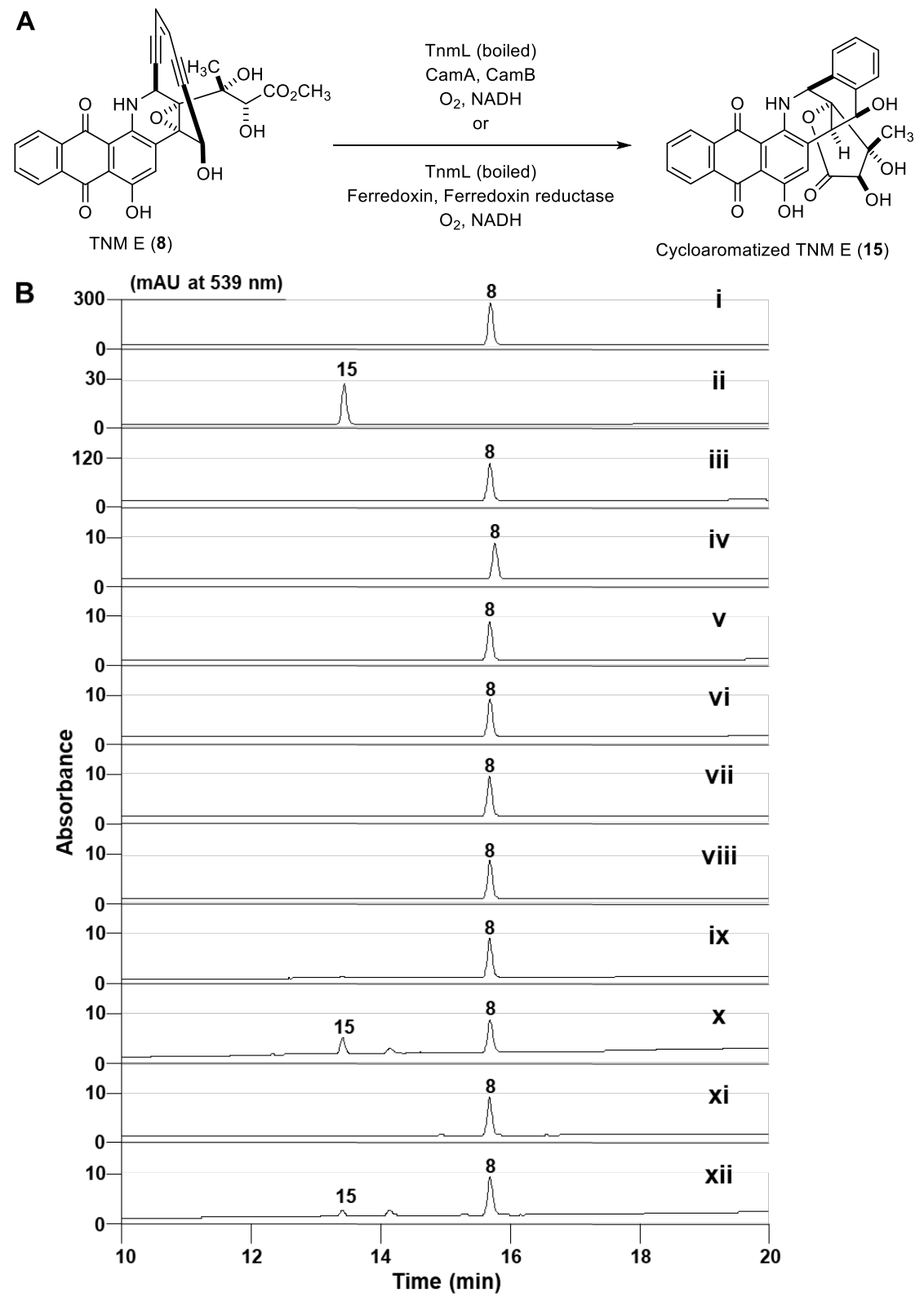
Figure S4. Determination of the optimal $\mathrm{pH}$ for TnmL. Activity of TnmL at different $\mathrm{pH}$ values using MES (blue), phosphate (orange), and Tris (grey) buffers. The optimal buffer and $\mathrm{pH}$ were determined to be $50 \mathrm{mM}$ phosphate buffer, $\mathrm{pH}$ 7.0. Error bars represent standard deviations.

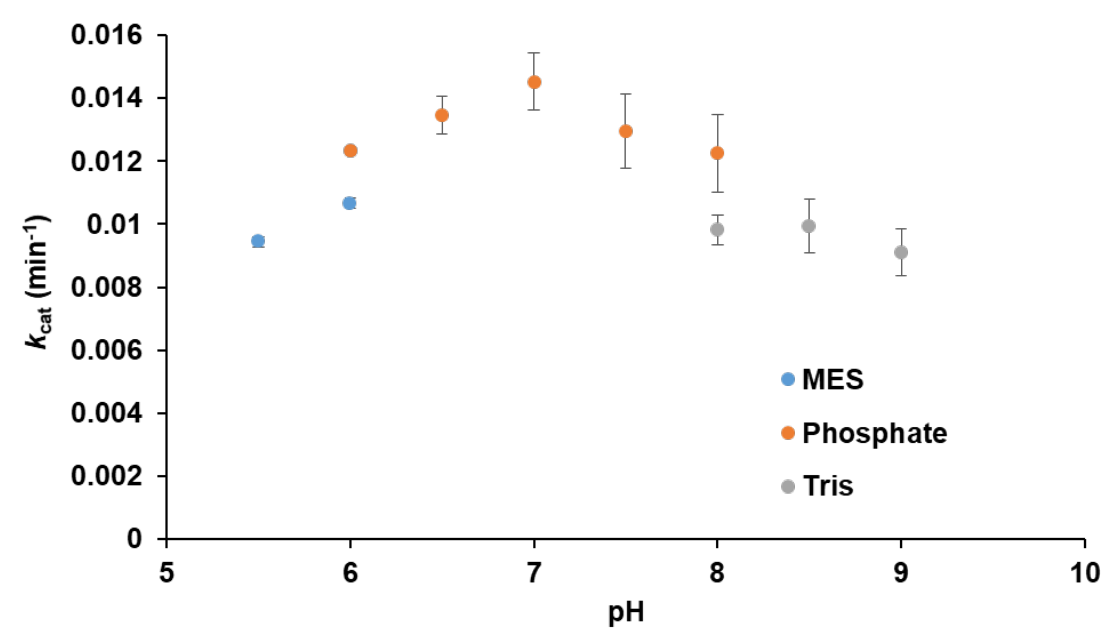

Figure S5. Determination of the optimal $\mathrm{H}_{2} \mathrm{O}_{2}$ concentration for TnmL. Activity of TnmL at different $\mathrm{H}_{2} \mathrm{O}_{2}$ concentration values $(0.5,2,5,20,50$ and $500 \mathrm{mM})$ TNM E (8) (blue) and TNM F (9) (orange) substrates. The optimal $\mathrm{H}_{2} \mathrm{O}_{2}$ concentration was determined to be $5 \mathrm{mM}$. Error bars represent standard deviations.

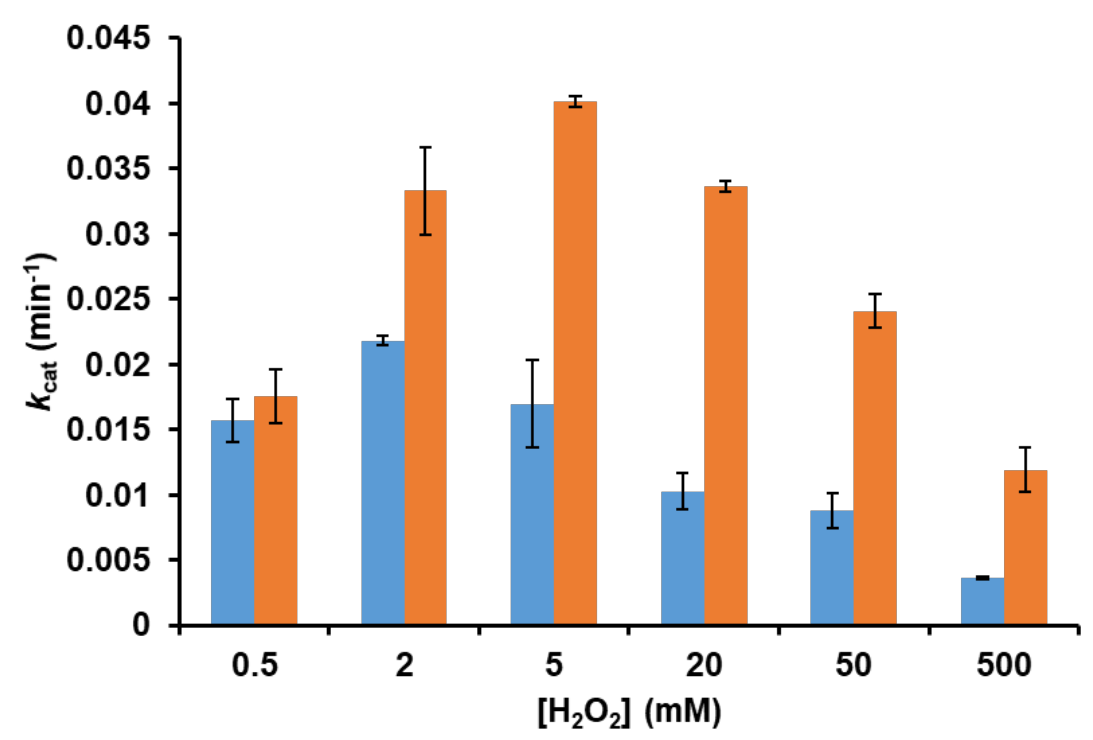


Figure S6. Calibration curve for TNM F (9) for quantitative analysis by HPLC at $\lambda_{539}$. Absorbance was measured at $0.02,0.1,0.5,2$ and $4 \mu \mathrm{M}$ of 9 using HPLC method III. We used the equation $\mathrm{Abs}_{539 \mathrm{~nm}}=19.613 \mathrm{x}$ [TNM F] for the quantification of the reaction product. Error bars represent standard deviations.

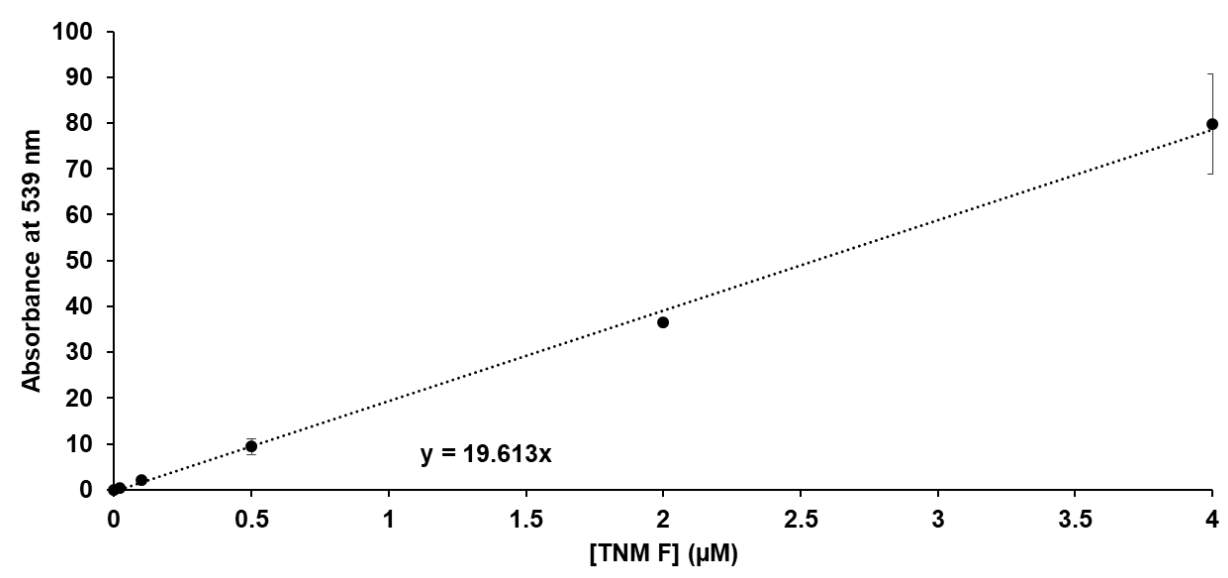

Figure S7. Calibration curve for TNM C (10) for quantitative analysis by HPLC at $\lambda_{539}$. Absorbance was measured at $0.05,0.1,0.5,2$ and $4 \mu \mathrm{M}$ of $\mathbf{1 0}$ using HPLC method III. We used the equation $\mathrm{Abs}_{539 \mathrm{~nm}}=12.247 \mathrm{x}$ [ TNM C] for the quantification of the reaction product. Error bars represent standard deviations.

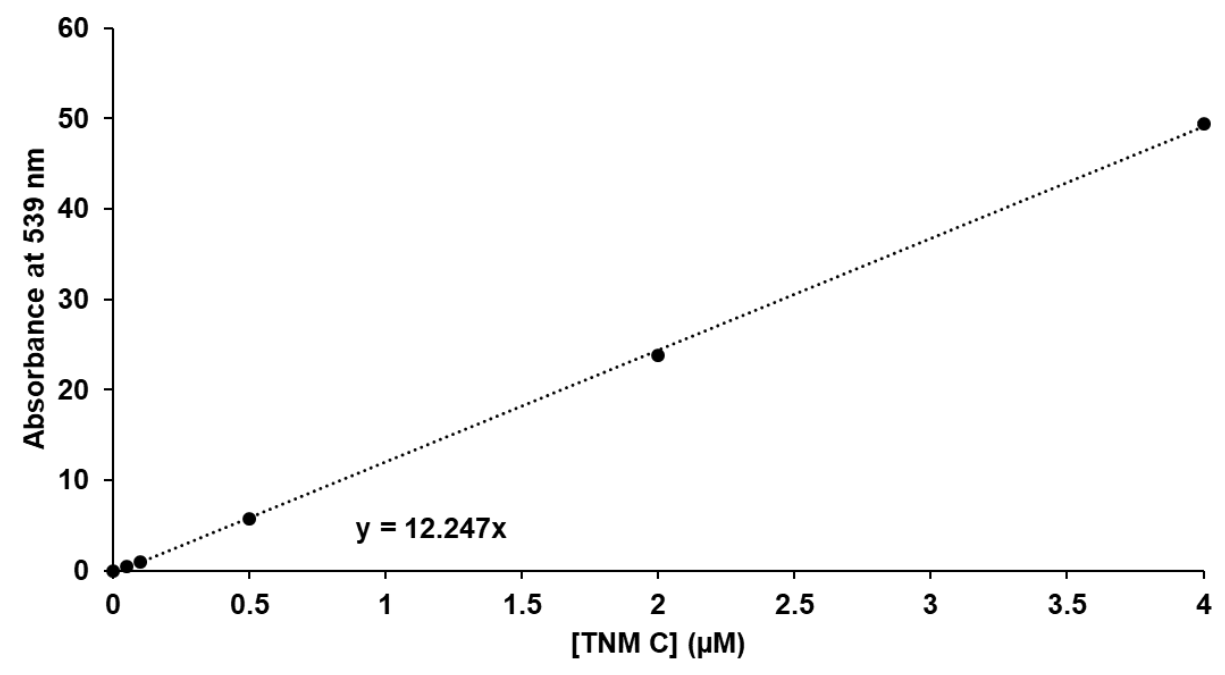


Figure S8. Steady-state kinetics for TnmL-catalyzed hydroxylation of 8 and 9. (A) MichaelisMenten curve generated from varying concentrations of 8. (B) Michaelis-Menten curve generated from varying concentrations of 9 .
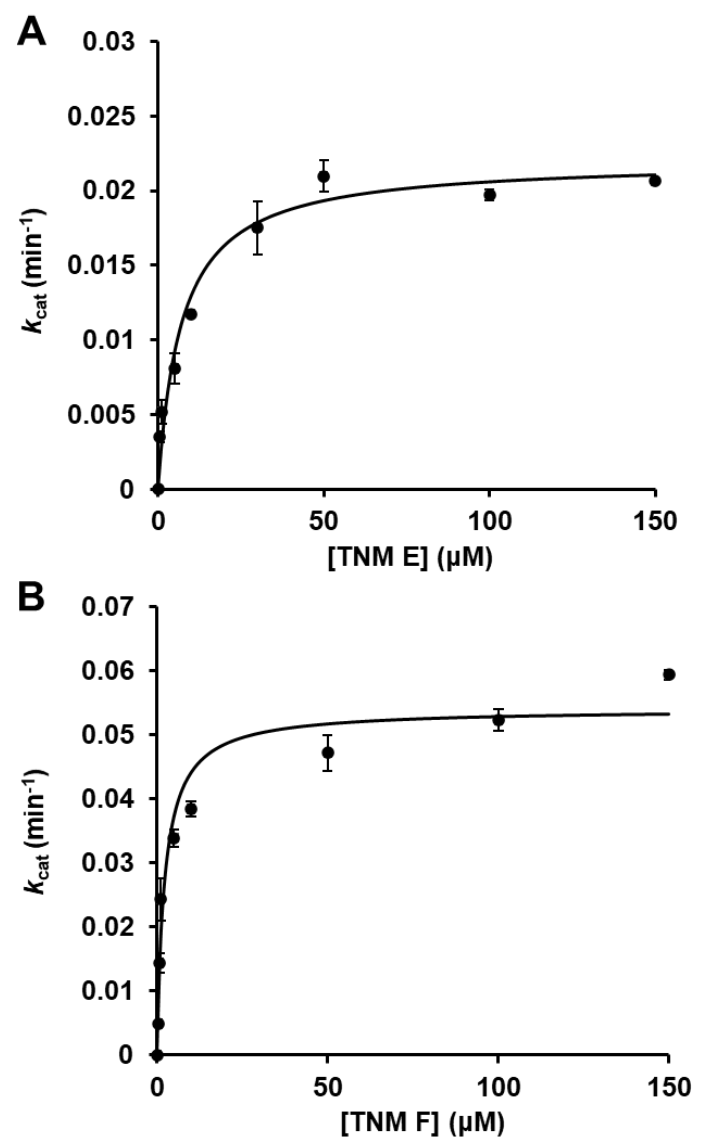
Figure S9. In vitro assays of TnmL-catalyzed hydroxylation of alternative substrates using $\mathrm{H}_{2} \mathrm{O}_{2}$ as a surrogate to redox partner to drive P450 catalysis. (A) Structures of the alternative substrates tested. (B) HPLC analysis, using method II, of the assay reactions: (i) reaction of TnmL with TNM B (7); (ii) reaction of boiled TnmL with 7; (iii) reaction of TnmL with the cycloaromatized product of 7; (iv) reaction of boiled TnmL with cycloaromatized product of 7; (v) reaction of TnmL with UCM (2); (vi) reaction of boiled TnmL with 2; (vii) reaction of TnmL with YPM A (3); (viii) reaction of boiled TnmL with 3 .
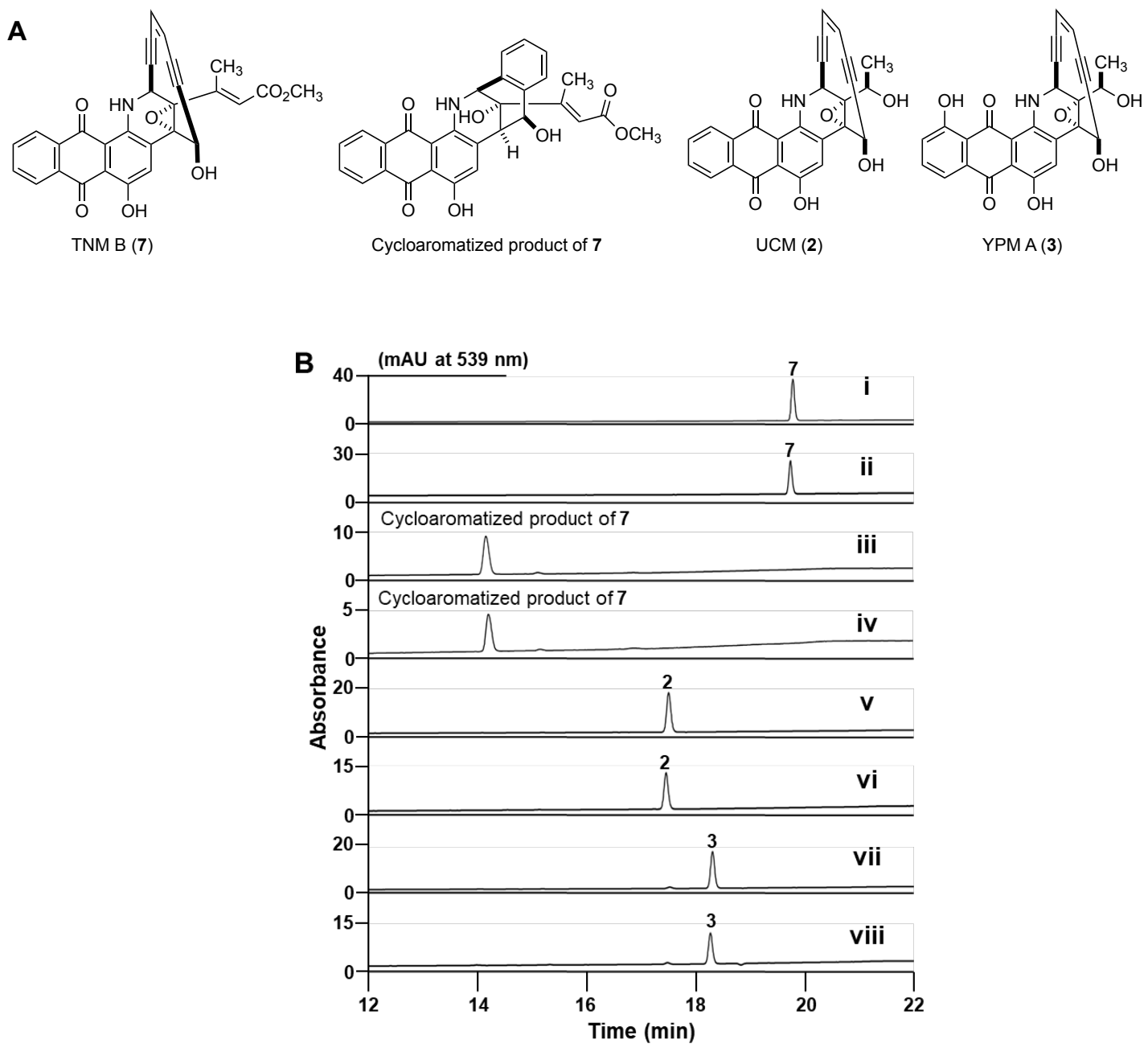
Figure S10. Binding assays of TnmL with (a) TNM E (8); (b) TNM F (9); (c) TNM C (10); (d) TNM D (12); (e) TNM G (11); (f) TNM B (7); (g) the cycloaromatized product of 7; (h) UCM (2); (i) YPM A (3).
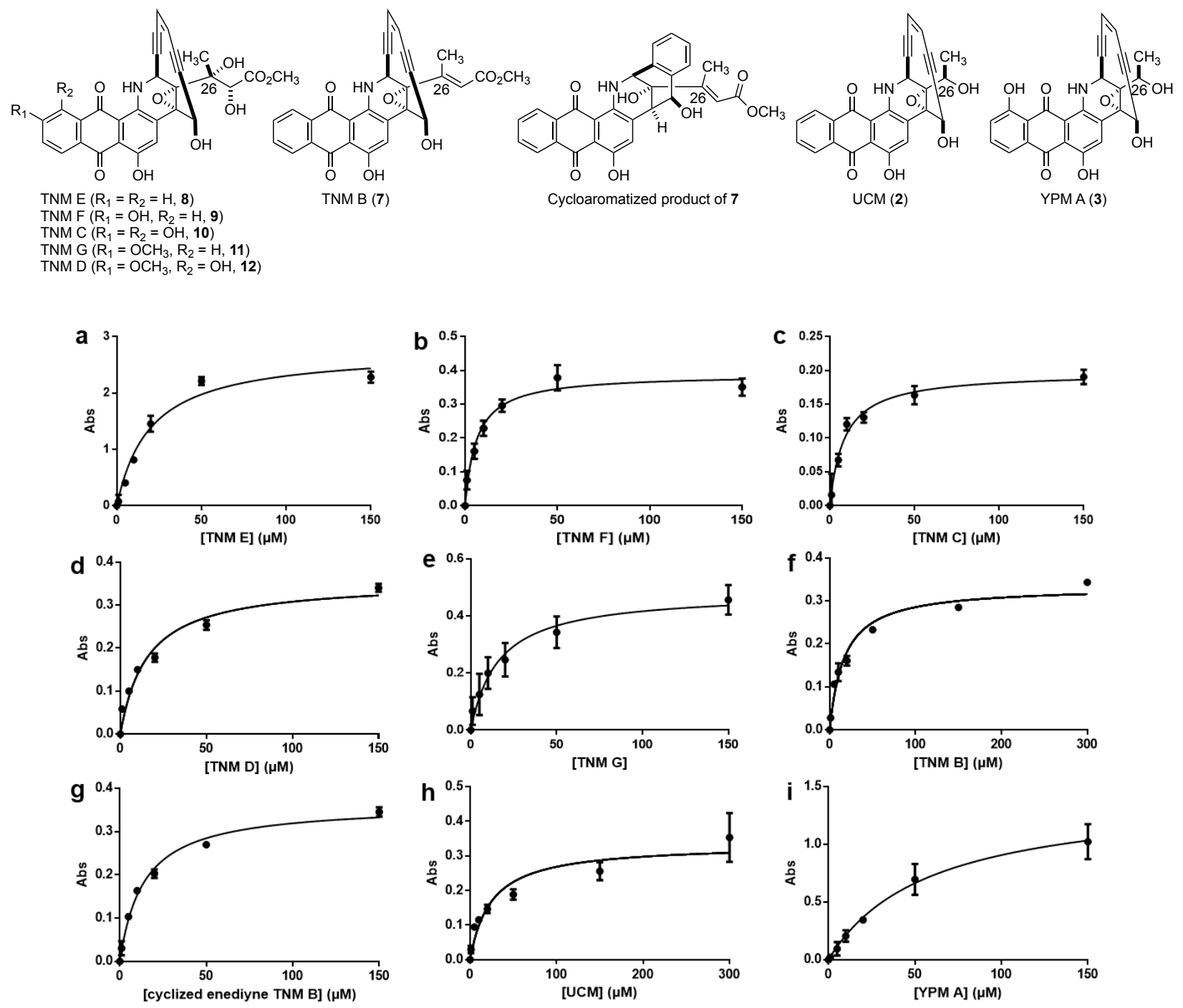
Figure S11. TnmL-catalyzed net demethylation reaction in TNM A biosynthesis by first TnmLcatalyzed hydroxylation of the $\mathrm{C}-7 \mathrm{OCH}_{3}$ of TNM G (11) followed by hydrolysis of the resultant hemiacetal product to afford TNM F (9).

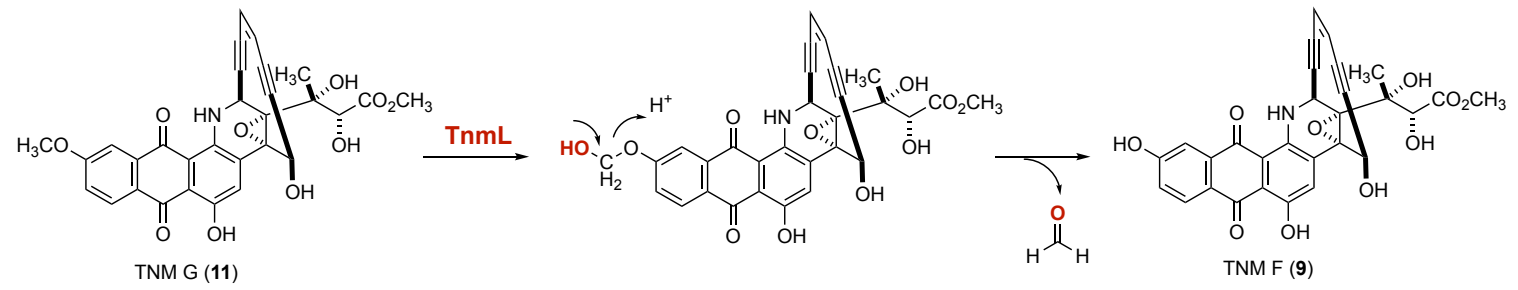

\section{References}

(1) Yan, X., Ge, H., Huang, T., Hindra, Yang, D., Teng, Q., Crnovcic, I., Li, X., Rudolf, J. D., Lohman, J. R., Gansemans, Y., Zhu, X., Huang, Y., Zhao, L.-X., Jiang, Y., Nieuwerburgh, F. V., Rader, C., Duan, Y., and Shen, B. (2016) Strain prioritization and genome mining for enediyne natural products. mBio 7, e02104-16.

(2) Yan, X.; Chen, J. J.; Adhikari, A.; Teijaro, C. N.; Ge, H.; Crnovcic, I.; Chang, C. Y.; Annaval, T.; Yang, D.; Rader, C.; Shen, B. (2018) Comparative studies of the biosynthetic gene clusters for anthraquinone-fused enediynes shedding light into the tailoring steps of tiancimycin biosynthesis. Org. Lett. 20, 5918-5921.

(3) Adhikari, A.; Teijaro, C. N.; Yan, X.; Chang, C.-Y.; Gui, C.; Liu, Y.-C.; Crnovcic, I.; Yang, D.; Annaval, T.; Rader, C.; Shen, B. (2020) Characterization of TnmH as an $O$ methyltransferase revealing insights into tiancimycin biosynthesis and enabling a biocatalytic strategy to prepare antibody-tiancimycin conjugates. J. Med. Chem. 63, 8432-8441.

(4) Guengerich, F. P.; Martin, M. V.; Sohl, C. D.; Cheng, Q. (2009) Measurement of cytochrome P450 and NADPH-cytochrome P450 reductase. Nat. Protoc. 4, 1245-1251.

(5) Peterson, J. A.; Lorence, M. C.; Amarneh, B. (1990) Putidaredoxin reductase and putidaredoxin. Cloning, sequence determination, and heterologous expression of the proteins. J. Biol. Chem. 265, 6066-6073.

(6) Zanetti, G.; Curti, B. (1980) Ferredoxin-NAPD ${ }^{+}$oxidoreductase. Methods Enzymol. 69, 250255.

(7) Myers, A. G.; Kort, M. E.; Cohen, S. B.; Tom, N.J. (1997) Enzymatic activation of DNA cleavage by dynemicin A and synthetic analogs. Biochemistry 36, 3903-3908.

(8) Jefcoate, C. R. Measurement of substrate and inhibitor binding to microsomal cytochrome P450 by optical-difference spectroscopy. In Methods in Enzymology, Fleischer, S.; Packer, L., Eds. Academic Press: 1978; Vol. 52. 258-279.

(9) Isin, E. M.; Guengerich, F. P. (2006) Kinetics and thermodynamics of ligand binding by cytochrome P450 3A4. J. Biol. Chem. 281, 9127-9136.

(10) Denisov, I. G.; Makris, T. M.; Sligar, S. G.; Schlichting, I. (2005) Structure and chemistry of cytochrome P450. Chem. Rev. 105, 2253-2277.

(11) Munro, A. W.; McLean, K. J., Grant, J. L.; Makris, T. M. (2018) Structure and function of the cytochrome P450 peroxygenase enzymes. Biochem. Soc. Trans. 46, 183-196. 